\title{
O społecznej koncepcji i jej artystycznym wcieleniu w Ostapie Bondarczuku Józefa Ignacego Kraszewskiego
}

\author{
About the social concept and its artistic \\ embodiment in Ostap Bondarczuk \\ by Józef Ignacy Kraszewski
}

\section{Wprowadzenie}

Fabuła Ostapa Bondarczuka' (1849), jednej z powieści ludowych Józefa Ignacego Kraszewskiego, sprawia wrażenie typowej romantycznej intrygi. Akcja toczy się w I8I2 r. na Wołyniu po przemarszu wojsk napoleońskich. Wieś i dwór zostały zniszczone i wyludnione. Ruin pilnuje zarządca, który kradnie skarb hrabiego. Ale Ostap, sierota ze wsi, świadek kradzieży, wskazuje złodzieja. Hrabia, a raczej jego żona, z litości przyjmuje go pod swój dach. Chłop otrzymuje wolność i wykształcenie, ale czuje się obcy i nieszczęśliwy w środowisku arystokracji.

Jednak powieści J.I. Kraszewskiego nie można sprowadzić tylko do problemu nierówności społecznych panujących w XIX w. Ostap Bondarczuk stanowi panoramę tamtego świata, przedstawia egzystencjalny niepokój pisarza i jego wrażliwość na „podziemne szumy” przeszłości i przyszłości. Jeszcze bardziej złożony jest podtekst historyczny i kulturowy, pełniący rolę magnesu, który wyznacza linie siłowe narracji. Punktem wyjścia jest odwieczny problem nierówności. Zawsze w świecie społecznym byli i ludzie

\footnotetext{
* Кам'янець-Подільський Національний університет ім. Івана Огієнка. Кафедра
} слов'янської філології та загального мовознавства.

1 J.I. Kraszewski, Ostap Bondarczuk, Lwów 1875. 
zdrowi, i chorzy, szaleni, niepełnosprawni, którzy mogli liczyć tylko na miłosierdzie innych oraz Boga. Chrześcijaństwo uznało, że wszyscy mają równe prawa do miłosierdzia i sprawiedliwości, jednak równość społeczna jest utopią. Nowoczesność przekształciła chrześcijańską ideę w koncepcję powszechnej równości wszystkich i wszystkiego nie w „wieczności”, ale „tu i teraz”. Rewolucja Francuska i epoka napoleońska były punktem zwrotnym, wyzwalającym pragnienie każdej jednostki ludzkiej, aby cieszyć się równymi prawami z innymi. Zbiegło się to z początkiem intensywnej urbanizacji i odejścia od archaicznego świata tradycyjnej wsi.

W Polsce nie było niewolnictwa ${ }^{2}$, które jednak miało miejsce w Rosji ${ }^{3}$, ale poddaństwo chłopów i pańszczyzna były do niego podobne. Polska szlachta wykreowała kilka mitów mających na celu uzasadnienie nierówności społecznych. Pierwszy z nich głosił, że szlachta pochodzi od Jafeta, a chłopstwo - od Chama, „którego potomstwo zostało w Biblii potępione i skazane na podrzędną rolę społeczną" ". Słowo „cham” stało się w pewnym okresie synonimem „chłopa”. Drugi mit wyjaśniał korzenie szlachty, która miała pochodzić od starożytnego plemienia rycerskiego Sarmatów, które podbiło Słowian ${ }^{5}$. Ów mit spełniał dwie funkcje: „spajał tożsamość narodu szlacheckiego oraz utrwalał jego hegemonię [...] wobec Chama" ${ }^{6}$.

2 Innego zdania jest m.in. Jan Sowa, który pisze: „Porządek społeczny panujący na wsi polskiej pomiędzy XVI a XIX wiekiem zasługuje ze wszech miar na miano niewolnictwa. [...] Szlachecki pan sprawował nad pańszczyźnianym chłopem władzę taką samą, jak właściciel niewolników: decydował o tym, czy chłop może opuścić wieś oraz kim mają być jego dzieci - które musiały zostać we wsi i pracować na polu - kontrolował nie tylko w stu procentach czas jego pracy, ale również czas wolny, zmuszając chłopów do zakupu we własnej karczmie produkowanego prze siebie alkoholu”. J. Sowa, Inna Rzeczpospolita jest możliwa! Widma przesztości, wizje przysztości, Warszawa 2015, s. 57-58. Zob. też: K. Pobłocki, Chamstwo, Wołowiec 2021.

3 Feudalne przywileje uzyskane przez wąskie elity zadecydowały o całkowitym pozbawieniu praw chłopa, który prawie cały tydzień odrabiał pańszczyznę, a nawet zdegradowany do stanu robotnika pracował za jałmużnę. Pan był zarówno „żywicielem rodziny”, jak i sędzią, który mógł odebrać życie. W I503 r. zakazano chłopom swobodnego przemieszczania się. Andrzej Frycz Modrzewski w XVI w. pisał, że szlachcic uważał chłopa za psa, a Siegmund von Herberstein odnotował niesłychany ucisk i bezprawie wobec zwykłych ludzi (Rerum moscoviticarum commentarii, Bazylea 1549). Por.: L. Bazylow, Spoteczeństwo rosyjskie w pierwszej potowie XIX w., Wrocław 1973.

4 L. Stomma, Polskie ztudzenia narodowe, Poznań 2006, s. 47. Szerzej zob.: A. Leszczyński, Ludowa historia Polski. Historia wyzysku i oporu. Mitologia panowania, Warszawa 2020, s. 16-23; J. Matuszewski, Geneza polskiego chama. Studium semazjologiczne, „Acta Universitatis Lodziensis" 1982, Folia iuridica, t. XI, s. IO-45.

5 Szerzej zob.: A. Leszczyński, dz. cyt., s. 23-31.

6 M. Rauszer, Chtop - niewolnik? Pańszczyzna w perspektywie antropologii historii, „Lud” 2017 , t. IOI, s. I2I. 
W wieku XVIII w Rzeczpospolitej rozpatrywana była kwestia, czy chłopstwo jest rzeczywiście częścią narodu polskiego.

W XIX stuleciu w kulturze polskiej rozwinął się inny mit, który można obserwować w utworach literackich. Na prawobrzeżnej Ukrainie, która została wcielona do Imperium Rosyjskiego po III rozbiorze Rzeczpospolitej, szlachta polska i ruska, zrównana ze szlachtą rosyjską, posiadała wsie zamieszkane najczęściej przez chłopów - w przeważającej liczbie Rusinów, którzy podobnie jak w Polsce byli przypisani do ziemi i odrabiali pańszczyznę. W okresie, ujętym w powieści J.I. Kraszewskiego, był to obszar rolniczy, eksploatowany gospodarczo przez szlachtę, a magnackie siedziby tworzyły bajeczne zespoły architektoniczno-krajobrazowe, jak na przykład majątek Potockich pod Humaniem, opiewany przez Stanisława Trembeckiego w poemacie Sofjów $k^{7}$ (1806). Z kolei w romantycznej powieści Zygmunta Miłkowskiego Wasyl Hotub (1858) pobrzmiewa idea nierozerwalnej jedności Polski i Ukrainy nawiązująca do tradycji I Rzeczypospolitej: „Jedna ziemia jest naszą matką"8. Jednak słowa te można rozpatrywać jedynie w kategoriach życzeniowych, ponieważ autor jakby nie zauważał ówcześnie panujących stosunków społecznych. Należy pamiętać, że likwidacja Polski szlacheckiej w końcu XVIII stulecia i objęcie ziem ukrainnych władztwem rosyjskim nie wpłynęło na zmianę stosunków społecznych na tym terenie. Prawobrzeżna i południowa Ukraina pozostały nadal zróżnicowane pod względem etnicznym i religijnym ${ }^{9}$. Rzeczywisty antagonizm między poddanymi (chłopami) i Kozakami a panami (zazwyczaj polską szlachtą) ujawniały liczne wystąpienia chłopskie, czy ruch hajdamacki ze znanym w historiografii po nazwą koliszczyzny powstaniem w Humaniu w 1768 r. ${ }^{10}$ Po stłumieniu buntów ukraińscy chłopi nadal pozostawali w sferze dominacji polskiej szlachty. Nie zmieniły tego stanu przepisy wymierzone w polską własność ziemską wprowadzone po upadku

7 S. Trembecki, Sofjówka, Warszawa 2000.

8 T.T.Jeż [Zygmunt Miłkowski], Wasyl Hotub, Kraków 1909, s.3.

9 M.Nagielski, Ukraińcy, [w:] Pod wspólnym niebem. Narody dawnej Rzeczypospolitej, pod red. M. Kopczyńskiego i W. Tygielskiego, Warszawa 2010, s. 77.

10 W kulturze ukraińskiej koliszczyzna utrwaliła się głównie dzięki twórczości Tarasa Szewczenki (W.W. Sokyrska, T. Strogosz, Hajdamacy i koliszczyzna w historiografii polskiej i ukraińskiej. Polsko-ukraiński dwugtos, „Przegląd Nauk Historycznych” 2017, nr 2, s. 8). T. Szewczenko włożył w usta swojego bohatera - Warnaka - znamienne słowa: „Wytnąłem wszystko, co nazywano panem, bez litości i zła”. Zob.: T.G. Ševčenko, Povne zibrannâ tvoriv. U I2 t., red. M.G.Žylins'kij ta ìn., t. 2: Poeziâ I847-I86I, Kïv 2001 [Т.Г. Шевченко, Повне зібрання творів. У $I 2$ m., реА. М.Г. Жулинський та ін., т. 2: Поезія I847-I86I, Київ 200I], s. 76. Jednak w finale poeta zmusza romantycznego złoczyńcę do pokuty i ponownego zwrócenia się ku Bogu. 
powstania styczniowego". Sytuacja chłopów znajdujących się pod berłem carów Rosji nadal była tragiczna.

J.I. Kraszewski nie widział w tej sytuacji idylli; w pamflecie Ukrainomania, napisanym dziesięć lat przed Ostapem Bondarczukiem, krytykował epigonów „szkoły ukraińskiej”, którzy portretowali piękno Ukrainy, zapominając o złożoności relacji między dwoma stanami i dwoma narodami. Dlatego ukraiński chłop, tytułowy Ostap, w obrębie szlacheckiego życia jest u J.I. Kraszewskiego nie tylko koncepcją romantyczną, ale i rodzajem "próbnej wersji” realizacji tej sielanki. Wydaje się, że zadaniem, jakie postawił przed sobą autor powieści, jest wyjaśnienie, dlaczego ta sielanka się nie udała.

\section{Pozycja autora i jej interpretacja w krytyce}

J.I. Kraszewski od młodości skłaniał się ku radykalizmowi, idei sprawiedliwości publicznej, przez co był prześladowany przez władze rosyjskie. Ale z czasem stał się prawdziwym etnografem, który dobrze znał wieś i zawiłość stosunków polsko-ukraińskich. Ukrainomania powstała rok po przeprowadzce pisarza z Grodzieńszczyzny na Wołyń w i 838 r., gdzie J.I. Kraszewski zajął się rolnictwem w swoim majątku. Był przeciwnikiem pańszczyzny, a nawet na kongresie prowincjonalnej szlachty w i 858 r. przedstawił memorandum w sprawie uwłaszczenia chłopów.

W oczach populistycznego skrzydła rosyjskich krytyków J.I. Kraszewski odgrywał rolę „obrońcy ludu” w duchu Nikołaja Niekrasowa, Tarasa Szewczenki itp. Dina S. Prokofjewa pisze o tej sytuacji następująco:

Autor artykułu jubileuszowego w „Russkich Wiedomostiach” (ı879, nr 243), analizując dorobek literacki Kraszewskiego, najwyżej ocenił jego powieści chłopskie, nacechowane „życiową prawdą” i „głęboką uczuciowością”. [...] Przytaczając wypowiedź jubilata na temat jego własnej twórczości „Swój czarny chleb wypiekałem przez całe pół wieku”, gazeta podkreśla, że na tym właśnie chlebie, istotnie zdrowym i powszednim, wychowało się kilka pokoleń; pokoleń, witających wyzwolenie chłopów równie gorąco, jak młodzież rosyjska lat $60-\mathrm{ych}^{12}$.

1 T. Epsztein, Wielka wtasnosśc ziemska w gubernipodolskiej na tle Ukrainy Prawobrzeżnej wXIX wieku, „Studia z Dziejów Rosji i Europy Środkowo-Wschodniej” 2018, nr I, s. 28-3I.

12 D.S. Prokofjewa, Józef Ignacy Kraszewski w prasie rosyjskiej drugiej potowy XIX wieku, „Pamiętnik Literacki” 1965, z. 2, s. 521-522. 
J.I. Kraszewski wykorzystał ten temat jako artysta słowa ${ }^{13}$. Wiele uwagi poświęcono „wątkowi chłopskiemu” w jego prozie, co wiąże się z charakterem jego programu artystycznego. Swietłana Malukowicz (Светлана Аементьевна Мамюкович) słusznie zauważyła:

Decydującą rolę w rozwoju realizmu Kraszewskiego odegrał rozwój tematu chłopstwa. Nawiązanie do niego w Ostapie Bondarczuku i innych dziełach było przejawem jakościowo nowej fazy humanizmu pisarza. Kraszewski ukazuje wybitną naturę chłopa, jego talent i człowieczeństwo, ukazuje wzrost samoświadomości ludu, ukazuje właścicieli ziemskich i chłopów nie tylko w sferze stosunków moralnych, ale i w sumie uwarunkowań politycznych, społecznych i ekonomicznych ${ }^{14}$.

Jednak S. Malukowicz poruszyła problem w duchu nauki radzieckiej, właściwie interpretując procesy społeczne „przez literaturę”. Od tego czasu krytyka literacka rozwinęła się, także w analizie "tematu chłopskiego": wymiar socjologiczny nie traci sensu, ale przestaje być celem samym w sobie ${ }^{15}$.

Niestety, niektórzy autorzy próbują wcisnąć J.I. Kraszewskiego w stare schematy. Katerina Kosiakewicz (Катерина Косякевич) ${ }^{16}$ pisze, że idee

13 J. Kijas, Kraszewski wobec kwestii chtopskiej w latach I840-1862, „Zeszyty Naukowe Uniwersytetu Jagiellońskiego”, nr I3, „Seria Nauk Społecznych, Filologia. Prace Historyczno-Literackie", z. 3, Kraków 1957, s. 145-200.

14 Tłumaczenie tekstu: autor. Oryginał zob.: S.D. Malûkovič, Stanovlenie realizma v tvorčestve Üzefa Kraševskogo (povesti i romany 30-4o-h godov), Diss.... kandydata filologičeskih nauk, Moskva 1984 [С.А. Малюкович, Становление реализма в творчестве Юзефа Крашевского (повести и романы зо-40-х годов), Аисс.... кандидата филологических наук, Москва 1984], s. 188.

15 Porównajmy: „Historia kotka w ptocie, jedna z żytomierskich powieści Kraszewskiego z I858 roku, zamykająca jego 'cykl' powieści ludowych, to prawdziwy majstersztyk. Autor kunsztownie splata w niej i zestawia dwa równoległe wątki fabularne. Opowiada „,historię" przemian tytułowego 'bohatera' - dąbczaka, wyrosłego na śródleśnej polanie, a potem nagle jednym cięciem chłopskiej siekiery pozbawionego kontaktu ze swoim naturalnym środowiskiem przyrodniczym, przeniesionego $\mathrm{w}$ świat rzeczy służących ludziom, w którym kolejno pełni funkcję kołka w płocie i ozdobnej laski anonimowego kolekcjonera. Jakby niezależnie od tej opowieści czytelnik śledzi perypetie pańszczyźnianego chłopa Sachara, obdarzonego przez Opatrzność samorodnym talentem artystycznym. Perypetie te rozsnute zostały na tle stosunków społecznych wsi poleskiej, współczesnej Kraszewskiemu, zaangażowanemu w latach pięćdziesiątych XIX wieku w spory wokół tak zwanej kwestii włościańskiej”. M. Lul, Drzewo, cztowiek i drobnoustroje w powieściowym laboratorium. O „Historii kotka w ptocie” Józefa Ignacego Kraszewskiego, „Annales Universitatis Paedagogicae Cracoviensis. Studia Poetica" 2020, nr 8, s. 142.

16 K. Kostâkevič, U̇zef İgnacij Kraševs'kij âk majster romantičnogo opisu ukraïns'kih selân XIX stolittâ, [w:] ÚzefKraševs'kij v kul'turnij spadŝini Ukraïni ta Pol'sì. Zbirnik 
wolności człowieka oraz równości jego praw i szans, protest przeciwko hierarchicznej strukturze społeczeństwa są wyraźne w twórczości pisarza, który w swej pracy (oryginał w języku ukraińskim ${ }^{17}$ ) połączył wartości oświecenia i romantyzmu. W interpretacji K. Kosiakewicz, Ostap jako reprezentant stanu chłopskiego posiada najlepsze cechy ludzkie. Jednocześnie brakuje mu heroizmu i umiejętności poprowadzenia ludowego powstania, ponieważ całą swoją siłę przeznaczył na bezowocne zaloty do infantylnej córki hrabiego (w rzeczywistości to córka hrabiego jest bardziej zakochana w Ostapie niż odwrotnie, ale nie przejmujemy się drobiazgami).

Pogląd, zaszczepiony niegdyś radzieckim badaczom, zgodnie z którym każdy pisarz rzekomo musi „wyrażać interesy zwykłego ludu”, jest wciąż obecny w świadomości postsowieckiej. Kierując się nim, inny badacz zarzuca J.I. Kraszewskiemu, że Ostap ze swoim losem zawieszonym między chłopstwem a arystokracją, wywołuje pewną irytację. Tak więc Lidia V.Zelinska ( $\Lambda$ іАія Володимирівна Зелінська) zarzuca autorowi „brak tematu mobilności społecznej”" : główny bohater Ostap cierpi z powodu swojego marginalnego miejsca w życiu, utraty tożsamości, niemożności identyfikacji. Niemniej jednak bezinteresownie służy hrabiostwu. Czy powinien był zabić hrabiego, swojego dobroczyńcę?

Nie zawsze można było uniknąć takich klisz i w Polsce, zwłaszcza w socrealizmie:

Utwory Kraszewskiego przyczyniały się również do rozbudzenia zainteresowań czytelniczych w środowisku wiejskim. Naszej oficynie szczególnie bliski pozostał Kraszewski jako autor powieści ludowych, w których po raz pierwszy kreował postacie z ludu w pełnym tego słowa znaczeniu, oraz

naukovih prac' (za materiatami mižregional'nogo naukowo-praktičnogo seminaru iz mižnarodnôे učastû, 20 grudnâ 2017 roku, m. Žitomir), Žitomir 2017 [К. Косякевич, Юзеф Ігнацій Крашевський як майстер романтичного опису українських селян ХІх століттля, [w:] Юзеф Крашевський в культурній спадщині України та Польщі. Збірник наукових пращь (заматеріаламиміжрегіонального науково-практичного семінару із міжнародною участю, го грудня 2017 року, м. Житомир), Житомир 2017], s. 76, 79 .

17 Û.İ. Kraševs'kij, Ostap Bondarčuk [Ю.І. Крашевський, Остап Бондарчук]. Dokument elektroniczny: http://testlib.meta.ua/book/22138/read/.

18 L.V.Zelìns'ka, Vidobražennâ „seredn’ogo klasu” u malârstvi ta literaturi Rosijskoï imperï dr.pol. XVIII - per. pol. XIX st., „Naukovì zapiski Nacìonal'nogo unìversitetu. Ostroz'ka akademiâ". Seriâ Fìlologična, Vip. 55, Ostrog 2015 [ $\Lambda$. В.Зелінська, $B i$ дображення „середнього класу” у малярстві та літературі Російськой імперї̈р. nол. XVIII - пер. nол. XIX cm., „Наукові записки Національного університету. Острозька академія". Серія Фікологічна, Вип. 55, Острог 2015], s. 100. 
ukazywał ogromną wartość kultury ludowej, a nawet jej wyższość nad kulturą szlachecką ${ }^{19}$.

Nawet dziś nie gaśnie pragnienie wywyższenia J.I. Kraszewskiego jako „mentora ludu” w literaturze: „Był przecież Kraszewski nie tylko człowiekiem XIX stulecia, który - w sposób świadomy lub nie - owo doświadczenie zmiany zawierał w tekstach osobistych; był w tym samym czasie niewątpliwie «nauczycielem narodu», jednym z najpoczytniejszych pisarzy krajowych" ${ }^{20}$. Tutaj pisarz zostaje wyniesiony na piedestał; nie oczekuje się od niego żywego słowa, ale „proroctwa”. Poniżej zobaczymy, że te oczekiwania nie są całkowicie bezpodstawne. Jednak gloryfikacja może prowadzić do tego, że wśród „zwykłych czytelników” stereotypowy obraz J.I. Kraszewskiego jako „wielkiego nudziarza” może „dzisiaj wyjść z lamusa na literacką agorę"21.

Niemniej jednak stanowisko J.I. Kraszewskiego wydaje się bardziej skomplikowane. Po pierwsze, pisarz nie musiał przyjmować punktu widzenia „Zwykłego człowieka”. Należący do polskiej arystokracji dokonał wnikliwej analizy pozycji własnej klasy, która traktowała bohatera jego powieści, młodego Ostapa, szlachetnie, ale nie uszczęśliwiła go. Po drugie, powieść świadczy o tym, że J.I. Kraszewski jako pisarz zajmował się nie tylko kwestiami aktualnymi, ale również ich historyczną i metafizyczną perspektywą.

Poważne podejście J.I. Kraszewskiego do „tematu chłopskiego” zakłada, powtarzam, zwrócenie uwagi na koncepcję artystyczną autora, a w szczególności na to, czy naprawdę można ją zredukować do romantyzmu lub realizmu? Ale jak dotąd kwestia ta nie została rozwiązana. Dominują spory w duchu wieku XIX: J.I. Kraszewski - romantyk czy realista? Z pewnością skłaniał się ku romantyzmowi; miejscami w jego twórczości „zasadniczą rolę odgrywa ironia romantyczna" ${ }^{22}$. Charakterystyczne jest to, że wielu

19 E.Zielonko, Józef Ignacy Kraszewski w wydaniach Ludowej Spótdzielni Wydawniczej, „Rocznik Towarzystwa Literackiego imienia Adama Mickiewicza” 1986, R. 21, s. 89.

20 M. Litwinowicz-Droździel, Józef Ignacy Kraszewski i choroby wieku, [w:] Kraszewski $i$ wiek XIX. Studia, red. A. Janicka, K. Czajkowski, P. Kuciński, Białystok 2014, s. 444.

21 M.Lul, Wielkim nudziarzem byt? Kraszewski, blogspoti czytanie klasyki, [w:] Kraszewski i wiek..., s. 196.

22 K. Grabias-Banaszewska, Sytuacja narracyjna wopowiadaniu Józefa Ignacego Kraszewskiego „Życiepóśmierci. Powieśćpijaka”, [w:] UzzefKraševs'kij vkul'turnij spadșini Ukrä̈n ta Pol'si. Zbirnik naukovih prac' za materiatami mižregional'nogo naukovo-praktičnogo seminaru iz mižnarodnoûu častû, 20 grudnâ 2017 roku, m. Žitomir, red. O.P. Polisisuk, B. Troha, V.O.Êršov, M.A. Kozlovec', N.A. Sejko, Žitomir 2017 [Юзеф Крашевський в культурній спадщині України та Польщі. Збірник наукових пращь за матеріалами міжрегіонального науково-практичного семінару із міжнародноюу частю, го грудня 
badaczy skupiło się - w duchu romantycznej krytyki - głównie na biografii pisarza i cechach jego osobistego stylu ${ }^{23}$.

Jednak pisarz jest także identyfikowany jako realista (pozytywista), który stara się zmieniać życie poprzez twórczość literacką ${ }^{24}$. Wiele jego prac jest uznawanych za pozytywistyczne, a same tematy niekiedy do takiej oceny prowokują. Są to np. Budnik - powieść o człowieku, który zajmował się karczowaniem lasów; Chata za wsia - o wykluczeniu Cygana przez obojętne środowisko; Garbucha - o starej kobiecie przygotowującej się do śmierci; szkic Profesor Milczek, napisany w duchu petersburskich „szkiców fizjologicznych"; i oczywiście - Ulana i Ostap Bondarczuk, w którym wyraźne są tendencje prepozytywistyczne. Ponadto, Dziad i baba, Nauczyciele sieroty, Gtupi Maciuś - oparte na folklorze i tradycji poetyckiej. Legendy historyczne przetwarza w: Królu chtopów, Starej baśni czy Hrabinie Cosel. Nie ma jednak powodu, aby klasyfikować te romantyczne stylizacje jako pozytywistyczne. Dlatego określenie J.I. Kraszewskiego jako twórcy polskiego realizmu brzmi kontrowersyjnie. Podstawy takiego stanowiska możemy znaleźć u Elizy Kąckiej, która cytując zdanie J.I. Kraszewskiego o potrzebie nowej artystycznej świadomości („nowy żywot lub zgon prowadzić za sobą mające. Stoimy na przełomie”), konstatuje, iż: „taki sposób bycia i myślenia, który umożliwiałby życie bliskie ideału silnie oddziaływającego na pokolenie Szkoły Głównej” "25. Jednocześnie krytycy, traktując o społecznej

2017 року, м. Житомир, реА. О.П. Поміщук, Б. Троха, В.О. Єршов, М.А.Козмовець, Н.А. Сейко, Житомир 2017], s. 41-46.

23 P. Chmielowski, Józef Ignacy Kraszewski. Zarys biograficzno-literacki, Kraków I888; K. Wojciechowski, Historia powieści w Polsce. Rozwój typów i form romansu polskiego na tle porównawczem, Lwów 1925; A. Bar, Charakterystyka i źródta powieści Kraszewskiego w latach 1830-1850, Warszawa 1934; M.Żmigrodzka, Proza fabularna w kraju, [w:] Obraz literatury polskiej XIX ${ }_{X X X}$ wieku, Seria 3, t. I: Literatura krajowa w okresie romantyzmu ${ }_{18}{ }_{31-I 863}$, red. M.Janion, B.Zakrzewski, M. Dernałowicz, Kraków 1975; E. Warzenica, „Powieści romantyczne” J.I. Kraszewskiego, [w:] $Z$ teorii i historii literatury. Prace poświęcone V. Międzynarodowemu Kongresowi Slawistów w Sofii, red. K. Budzyk, Wrocław-Warszawa-Kraków 1963.

24 K. Wojciechowski, dz. cyt., passim; A. Bar, dz. cyt., passim; J. Bachorz, Poszukiwanie realizmu. Studium o polskich obrazkach proza wokresie międzypowstaniowym I83I-I863, Gdańsk 1972; T. Budrewicz, „Zdrowie” $i$ „choroba” w jezyku Kraszewskiego (w okresie wotyńskim), [w:] tegoż, Kraszewski - przy biurku i wśród ludzi, Kraków 2004; E. Ihnatowicz, Proza Kraszewskiego. Codzienność, Warszawa 20ı; A.A. Kozłowska, Fizjonomiczne ślady w epoce pozytywizmu na przyktadzie "Dziwadel” J.I. Kraszewskiego, „Annales Universitatis Mariae Curie-Skłodowska” 2016, sectio FF - Philologia, vol. XxXIV, nr I, s. 25-39.

25 E. Kącka, Cztowiek wedtug Smilesa. Kraszewski pozytywistów (Struve, Chmielowski, Orzeszkowa), „Wiek xIx. Rocznik Towarzystwa Literackiego im. Adama Mickiewicza" 2012, R.V (47), s. 458. 
perspektywie J.I. Kraszewskiego, często wychodzą poza dychotomię romantyzm - realizm, czując, że określenia te nie w pełni oddają to zjawisko. Tak więc Wincenty Danek zauważył podobieństwo J.I. Kraszewskiego do weryzmu; Maria Żmigrodzka określiła jego styl jako biedermeier, czyli konflikt między ideałem a rzeczywistością ${ }^{26}$. Traktują spuściznę J.I. Kraszewskiego jako rodzaj pozycji „między romantyzmem a realizmem” ${ }^{27}$. Jednocześnie często zwraca się uwagę na złożoność stylistyki pisarza:

Kuriozalność sytuacji podkreśla fakt, iż to Kraszewskiego uważa się za reformatora polskiej powieści, wskazuje ogromny wpływ na te zabiegi konstruowania fabuły powieściowej, które opierały się na rzetelnej obserwacji, zbieraniu materiału dokumentalnego, naukowego. Uważa się, iż powieściopisarstwo Kraszewskiego dało podwaliny późniejszej polskiej powieści. [...] Jest twórcą nieobecnym, pomijanym mimo niewątpliwych walorów edukacyjnych $^{28}$.

Wydaje mi się, że zasługuje na szczególną uwagę pomysł wskazujący na to, że J.I. Kraszewski „od początku był w Polsce pisarzem bez jasnego przyporządkowania: trochę romantyk, ale trzeźwy [...] prepozytywista trochę"29. Ta definicja wydaje się bardziej wyważona i precyzyjna niż jednoznaczne wpisanie pisarza w szeregi romantyków czy realistów, a tym bardziej opinia o połączeniu tych dwóch systemów. Dziś mamy dość jasne kryteria definiowania pozytywizmu w prozie (np. koncepcje Henryka Markiewicza ${ }^{30}$ czy Michała Głowińskiego ${ }^{31}$ ). Uznanie Ostapa Bondarczuka za powieść pozytywistyczną jest błędem, jednak elementy propozytywistyczne w niej

26 W. Danek, Sylwetka ideowa J.I. Kraszewskiego, „Ruch Literacki” 1962, z.6; M.Żmigrodzka, Polska powieść biedermeierowska, „Pamiętnik Literacki” 1966, t. 52, z. 2.

27 K. Czachowski, Józef Ignacy Kraszewski, [w:] tegoż, Między romantyzmem a realizmem, Warszawa 1967; K.W.Zawodziński, Studia o Kraszewskim, [w:] tegoż, Opowieści o powieści, Kraków 1963.

28 D.Żok, Józef Ignacy Kraszewski - niedoceniony izapomniany wpolskiej szkole, [w:] Ûzef Kraševs'kij v kul'turnij spadŝini Ukraïni ta Pol'ši..., s. 24-25, 29.

29 J. Ławski, Józef Ignacy Kraszewski - nowe style lektury, „Volin'-Žitomirŝina” 2014, nr 25, [„Волинь-Житомирщина”. Історико-фімологічний збірник з регіональних проблем, Житомир 2014], s.91.

30 H. Markiewicz, Literatura pozytywizmu, Warszawa 1986.

31 W kontekście romantyzmu i pozytywizmu nie było wyraźnej granicy, między okresami, zgodnie z koncepcją M. Głowińskiego, narrację XIX-wieczną prowadziła „najbardziej wykrystalizowaną, najpełniejszą, najbogatszą postać” (M. Głowiński, Gatunek literacki i problemy poetyki historycznej, [w:] Proces historyczny w literaturze i sztuce. Materiaty konferencji naukowej. Maj 1965, Warszawa 1967, s. 52-54). 
występują; mieści się w kręgu tendencji polskiej prozy lat 40. wieku XIX ${ }^{32}$. Istnieje jednak różnica między wczesnym romantykiem J.I. Kraszewskim a dojrzałym realistą, ale w tej materii mamy do czynienia z pomieszaniem kategorii. Tak więc Svitlana Čornous (СвітланаЧорноус), wychodząc od stwierdzenia, że autor Ostapa Bondarczuka jest niewątpliwie romantykiem, w finale charakteryzuje pisarza już jako „przedstawiciela sztuki realistycznej, której kanonom pozostał wierny aż do ostatnich dni” (oryginał w języku ukraińskim); realizm był zdeterminowany ukraińską ziemią ${ }^{33}$. To samo stwierdza Nadiâ Petričenko (Надія Петриченко) - ukraińskie realia narodowe znajdują odzwierciedlenie w szeregu prozatorskich utworów autora, związanych tematycznie z kształtowaniem nowych kierunków ideologicznych w literaturze polskiej. W latach 50. XIX w. w twórczości wielu pisarzy, przede wszystkim u J.I. Kraszewskiego, dominują problemy chłopskie, które miały znaczący wpływ na rozwój realizmu. Ich znaczenie dla literatury polskiej, a także rosyjskiej i ukraińskiej, zostało utrzymane ze względu na aktualność kwestii chłopskiej jako takiej ${ }^{34}$.

Jednak rozważania o realizmie dojrzałego („ukraińskiego”) J.I. Kraszewskiego opierają się na pewnej deklaratywnej postawie autora, a nie na konkretnej analizie tekstu. Autor Ostapa Bondarczuka jakoby opisuje naturę, ukraińską rzeczywistość, którą ma przed oczami, co oznacza, że jest realistą. Tymczasem naturalizm wcale nie jest przejawem realizmu jako takiego, jest w stanie wejść w każdy system artystyczny, np. w „materialną” płaszczyznę symbolu w baroku czy symbolizmie. Warto przytoczyć konstatację Keren Gorodeisky: „specific task of characterizing romantic aesthetics adds to these difficulties an air of paradox" ${ }^{35}$.

32 Zob.: M.Żmigrodzka, Orzeszkowa. Mtodość pozytywizmu, Warszawa 1965; M.Janion, M.Żmigrodzka, Romantyzm i historia, Gdańsk 200I; I. Szulska, Litwa Józefa Ignacego Kraszewskiego, Warszawa 2011.

33 S. Čornous, Ukraïnika u tvorčosti Û.İ. Kraševs'kogo, „Kiïvs'kì Polonìstičnì Studiï” 2006, t. 7 : „Ukraïns'ka skola” v literaturi ta kul'turi ukraïns'ko-pol's'kogo pograniččâ, Kiї [С. Чорноус, Україніка у твориості Ю.І. Крашевського, „Київські Помоністичні Студіі” 2006, т. 7: „Українськашкола” влітературітакультуріукраїнсько-польськогопограничия, Київ],s. 354 .

34 N. Petričenko, Volin' i Žitomirŝina - druga bat'kivsîna Û.İ. Kraševs'kogo (ukrä̈ns'ki zacikavlennâ, tematika, žanrova naraciâ prozovoï spadsinini pis’mennika), „Volin’Žitomirŝina” 2009 [Н. Петриченко, Волинь $і$ Житомирщина - друга батьківщина Ю.І. Крашевського (українські зацікавлення, тематика, жанрова наращія прозової спадщини письменника), „Волинь-Житомирщина”. Історико-фімологічний збірник з регіональних проблем, Житомир 2009], nr 19, s. 62-70.

35 K. Gorodeisky, Igth Century Romantic Aesthetics, [w:] The Stanford Encyclopedia of Philosophy. Dostępny w Internecie: https://plato.stanford.edu/entries/aesthetics-19th-romantic/ (dostęp: I4 czerwca 2016). 


\section{Krajobraz i środowisko materialne w powieści Ostap Bondarczuk jako intensywne artystyczne kadrowanie losów bohatera}

Znaki losu Ostapa ukryte są implicite u J.I. Kraszewskiego w strukturze powieściowego pejzażu, który jest wyjątkowo delikatny jak akwarela. Oto przykład:

Spojrzyjmy na tę wioskę w dolinie, między dwoma pagórkami leżącą. Jeden z wzgórzów okryty dębowym laskiem, co się jeszcze nie rozwinął, drugi nagi i pokrajany w zarosłe już trawą skiby, lekko schodzą oba ku zielonej łące, co się pozłociła kwitnącą łotocią. Po nad rozlaną jeszcze na mnogie kałuże rzeczułką, przechadzają się poważnie czerwononogie bociany, polatuje czajka piskliwym odzywając się głosem, błądzą cyranki szukając zakrytego trzcinami źródliska ${ }^{36}$.

Ale ta panorama umiejscowiona jest w opisie ubogiej wołyńskiej chaty chłopskiej, która jest nie tyle „architekturą”, ile częścią przyrody jak jaskinia zwierzęcia. To właśnie w niej Ostap ujrzał światło. A taka chata wytrzyma ciężkie chwile - kto do niej wkroczy?

Chata wołyńskiego chłopka, warta jest zastanowienia doprawdy. [...] na Wołyniu, gdzie często całe wsie rózgi lasu nie mają, gdzie o materjał tak trudno, chata wieśniacza równie jest kunsztowną i ciekawą [...]. Ściany zarzucają się najrozmaitszego drzewa polanami; i nie myśleć im wcale o foremności, ciosać nie ma z czego, ułożyć się krzywe nie da prosto, często też i najczęściej w górze się wydmie, u dołu wklęsnie cieniuchna zapora, całą rodzinę rozdzielająca od zimowych niepogód i dojmujących wichrów. Zewnątrz i wewnątrz grubo wylepiona gliną, osmarowywana co roku, ogrodzona przyźbą, ziemią lub gnojem napełnioną; przecięta maleńkiem okienkiem, nad którem wisi kawał zwiniętej maty, chatka wieśniacza trwa jednak długie lata; ale jakże smutna jej zgrzybiałość! ${ }^{37}$

J.I. Kraszewski przedstawia zniszczony dwór. Niemoralność wojny budzi bestię w człowieku, niezależnie od skłonności politycznych. Napoleon nie miał bardziej lojalnych towarzyszy broni niż Polacy, ale dwór polskiego arystokraty, okupowany przez żołnierzy Napoleona w czasie działań wojennych, przedstawia smutny obraz: „A ludy, co się pastwiły tak nad strzechą

36 J.I. Kraszewski, dz. cyt., s. 8.

37 Tamże, s. 8-9. 
nieznanego, nie byli to barbarzyńce! O! nie! przyszli z ucywilizowanego zachodu, ale wojna rozbestwia" ${ }^{38}$. Pisarz z wyraźną goryczą, ale i tajemniczą ekstazą, wylicza zniszczenia pięknego materialnego świata:

I pałac w nielepszym był stanie. Większej części okien brakło szyb, a nawet ram, niektóre zamykały się okiennicami, inne zabite były dylami, inne stały otworem dla wróbli i jaskółek. Jedna z oficyn widocznie służyć musiała za stajnię, bo kupy przez okna wyrzucanego gnoju, dobitnie o tem świadczyły; druga w połowie pusta, w połowie zajęta przez rządcę, nieco w lepszym była stanie. Na froncie pałacowym, nie wiem jakim trafem, kula armatnia wybiła dziurę po nad samym spłókanym herbem dziedzica. Jaskółki ulepiły gniazdo w tej pamiątce wojny. Zniszczenie choć im posłużyło na coś. Wewnątrz smutno wnijść było. Dach połamany przepuszczał deszcz i tający śnieg, które strugami brudnej wody, płynęły na powybijane i powyrywane posadzki, na sztukaterje gipsowe, na malowane i mozajkowane ściany. Pałac sam opowiadał swoją historję. W sieniach postrzelane ściany, ruszona podłoga, zrąbane drzwi. W pokojach kupy popiołu i węgla, krzesła walały się bez nóg, stoły leżały na ziemi, kominki czerwonemi nagiemi świeciły cegłami. W jednej sali kilka familijnych obrazów posiekanych, pokiereszowanych, postrzelanych, bez nosów, bez oczu wisiały nieforemnie lub leżały na podłodze ${ }^{39}$.

Dwór jest zniszczony, a nędzna chłopska chata pozostaje nietknięta. Obraz ten przypomina hasło Rewolucji Francuskiej: „Pokój chatom, wojna pałacom!”. Jednak J.I. Kraszewski potrzebuje tej opozycji tylko po to, aby na początku zaakcentować kruchość miejsca, do którego Ostap zostanie przyjęty.

Biografia Ostapa, po głębszym zbadaniu, staje się podobna do wędrującej fabuły Kopciuszka, ale rozwinięta jest na materiale życia w epoce napoleońskiej w Europie. Spoglądając na tę fabułę z punktu widzenia krytyki rytualno-mitologicznej, można dostrzec w niej archetyp dziecka-znajdy. Carl Gustav Jung podkreśla tę właściwość archetypu, twierdząc że „po szczegółowym zbadaniu tych obrazów odkryjemy, że w pewnym sensie są one sformułowanym wynikiem rozległego, typowego doświadczenia przodków" 40.

38 Tamże, s. I2.

39 Tamże, s. IO-II.

40 K.G. Ûng, Ob. otnošenii analitičeskoj psihologii k poêtiko-hudožestvennomu tvorčestvu, [w:] tegoż, Sobranie soćinenij v Ig tt., t. Is: Fenomen duha v iskusstve i nauke, Moskva 1992 [К.Г.Юнг, Об отношении аналитической психологии к поэтикохудожественному твориеству, [w:] К.Г. Юнг, Собрание сочиненийв го тт., т. І5: Феномен духа в искусстве инауке, Москва 1992], s.117. 
Dodajmy, że w archaicznych mitach znajda, jako dar z Nieba, nieuchronnie staje się osobowością heroiczną ${ }^{41}$. Oznacza to, że Ostap, zgodnie z folklorem i modelem mitologicznym, musiał zrobić coś niezwykłego.

\section{Charakter powieści J.I. Kraszewskiego. Romantyczny monolit czy „dialektyka duszy"?}

Bohatera powieści poznajemy jako „szczenię wilka”, ścigane przez bezdomność dziecko z opuszczonej wioski:

Byłby mówił dalej, ale w tej chwili odarty dzieciak wyrwał się z gęstwiny i począł uciekać.Ze łzami spojrzała na dziecko hrabina. Było to dziecię wieśniacze, nędzne, żółte, wybladłe, sześć lub siedm lat mieć mogące, a tak odarte, że połowa ciała przez łachmany poczepiane świeciła. Siermiężka jego zlepiona z najróżniejszych szczętów, ledwie piersi i biodra okrywała; nogi bose, ręce nagie, głowa nie okryta była; a na bladej twarzy, pomimo przestrachu, cierpienia, śladów schorowania i wyniszczenia głębokiego, ujmujący wyraz łagodności panował. Siwe oczy we łzach pływały, a ściśnięte usta, kształtne, wązkie, choć sine, choć we wpadlych policzkach, nie śmiejąc wzywać litości, zarysowały przymuszony uśmiech, uśmiech biednych co za obowiązek sobie mają, pokrywać nim cierpienie i prosić miłosierdzia. Pomimo odarcia i przerażającej nędzy, bladości, wyschnienia, dziecię jeszcze było piękne, tą smętną pięknością zeschłych kwiatów, co się rozkwitną na gałązce rośliny zwarzonej jesienią ${ }^{42}$.

Ale Ostap pozostaje i tak samotny do samego końca; na nic doskonałe wykształcenie w Berlinie, miłość i bezinteresowna praktyka lekarska w swojej rodzinnej wsi.

Romantyzm przejmuje od klasycyzmu artystyczne uogólnienie, jakim jest idealizacja, czyli konstruowanie charakteru bohatera na podstawie jego dominującej cechy. Ta monolityczność formalnie przypomina klasycyzm. A realizm, zanurzenie człowieka $\mathrm{w}$ otoczeniu, w kontaktach społecznych, zmienia bohatera, czyni z niego postać złożoną i często sprzeczną. To już

41 R.G. Nazirov, Ditâv korzine iprimetyizobrannikov. Opytrekonstrukcji êtnografíceskogo substrata mifov, „Nazirovskij Arhiv” 2016 [Р.Г.Назиров, Аитя в корзине и приметь избранников. Опььт реконструкции этнографического субстрата мифов, „Назировский Архив” 2016], nr 4, s. I3. Dostępny w Internecie: nevmenandr.net/nazirov/journal.php. Zob. też: E. Nowina-Sroczyńska, Przezroczyste ramiona ojca. Etnologiczne studium o magicznych dzieciach, Łódź 1997.

42 J.I. Kraszewski, dz. cyt., s. 16-17. 
nie idealizacja, a typizacja. Charakterystyczne jest to, że badacze twórczości J.I. Kraszewskiego zwykle nie mają wątpliwości, czy jego bohaterowie mają złożone biografie ${ }^{43}$. Tak więc wystarczy jeden szczegół psychologiczny, aby przewidzieć los Ostapa. Chłopiec pomaga hrabiemu, wskazując złodzieja, a ten natychmiast zapomina o sierocie ze wsi. Żona hrabiego zlitowała się nad nim, ale klimat moralny w przyszłej rodzinie Ostapa jest już z góry określony - właśnie przez wewnętrzną niezmienność postawy głowy rodziny wobec Ostapa. Bohater, który nie uwolnił się całkowicie, pozostaje niezmienny; czuje się jak Konrad Wallenrod w domu, który nie stał się jego własnym.

Bohaterowie J.I. Kraszewskiego w swoim zachowaniu są tak naprawdę zdeterminowani społeczno-psychologicznie niemal fizjologiczną "predestynacją”. Tak więc syn hrabiego jest naznaczony - jako młody arystokrata - piętnem degeneracji i to jest jakby jego główna cecha:

Tak nawet jest; ale potomkowie wielkich rodzin, które przypadkiem, rachubą, ukradkiem, nie podsyciły się mniej szlachetną, a bujniejszą krwią ludu, przy wielkiej delikatności rysów, mają też właściwą sobie ich zdrobniałość. Nasz młody chłopiec, także miał rysy posągowe, oko wypukłe i kształtnie powieką ociągnięte, nos prześlicznych linij, czoło gładkie i wzniosłe, rączkę maleńką, nogę drobną jak kobieca. Ale wdziękowi i szlachetności kształtów, ujmował brak siły, jakieś wycieńczenie, znużenie, skarłowacenie, które łatwo postrzegłeś. Zdało się, jakbyś nań patrzał przez szkło zmniejszające, tak wszystko w nim zdrobniało, zmalało. - Życie nie płynęło falami po wzdętych jego żyłach, ale toczyło się powolnie, mozolnie, ciężko, a może nudno. Czarny lśniący włos, wcześniej niż należało, począł uciekać ze skroni i odsłaniać bardziej jeszcze czoło; barwa różowa zeszła z policzków młodych jeszcze, a już bladych i zmatowanych ${ }^{44}$.

A w Ostapie jest młodość, energia biologiczna i siła chłopskiej natury, lecz to cechy tylko potencjalne:

Drugi, obok siedzący, barczystszy, słuszniejszy, biały, rumiany, zbudowany na olbrzyma, rozrosły jak dąb na dobrej ziemi, z długim włosem blond

43 Tak więc zauważono, że w powieści Masłow J.I. Kraszewski po prostu dzieli bohaterów na „naszych” i „obcych”: „Всеиные факторы (возрастной, гендерный, др.) носят вторичный характер” [„Wszystkie inne czynniki (wiek, płeć itp.) mają charakter drugorzędny” - tłumaczenie autora]. Szerzej zob.: T.W. Sienkiewicz, Intertekstual'nost' romana "Maslav" Û.I. Kraševskogo, [w:] Kraszewski i wiek XIX... [T.W.Sienkiewicz, Интертекстуальность романа „Маслав” Ю.И. Крашевского, [w:] Kraszewski i wiek ХІХ...], s. 640.

44 J.I. Kraszewski, dz. cyt., s. 21-22. 
i niebieskiem okiem, z malinowemi usty; tęskno także, choć wcale inaczej patrzał. Jego milczenie więcej daleko mówiło. Zrzucony kapelusz, rozpierzchłe włosy, zdarta rękawiczka, zgięty kij w ręku silnem, dowodziły gry namiętnej wewnątrz. Oczy błądziły po przechadzce, a każde odebrane wrażenie pisało się wyraźnie, jasno, na niezastygłem jeszcze obliczu. Co uczuł, to wyrażał w tejże chwili, całym sobą ${ }^{45}$.

Można by się spierać, czy nie obserwujemy tu podejścia do jednej z najbardziej istotnych motywacji rozwoju postaci w realizmie - wpływu otoczenia na kształtowanie osoby, nawet w burzliwej epoce napoleońskiej? Może autor opiera się na „pierwotnych siłach” podkreślonych przez pozytywistę Hipolita Taine'a (rasa, środowisko, moment historyczny)? Może nieszczęścia i trudności, jakich doświadczył bohater, pozostawiły w jego umyśle zbyt głębokie rany?

Nie, środowisko społeczne w powieści jest przedstawione dość płynnie. Oto obrazy życia, przepływające wyłącznie "publicznie”, sceny z życia świeckiego; szczegółowe, plastyczne opisy „rozlane” w energicznym tempie. Dominują dialogi. A psychologia bohatera jest „rzeczą samą w sobie”. Pisarz mówi „w imieniu bohatera”, nie zanurzając nas w swoim wewnętrznym świecie:

Ostap szedł z uczuciem nieopisanej tęsknoty przez wieś, szukając rodzinnej chaty. Pamięć jego żywo mu przedstawiała miejsce na którem stała, zgliszcze spalonego domostwa, rozwalony piec, sterczące nie dogorzałe węgły. - Szedł z bijącem sercem ku niemu, ale inaczej je znalazł. Podwórko zagrodzone, chata nowa - stara tylko grusza jeszcze się trzymała, jakby na świadectwo że było zgliszcze. Poznał Ostap rodzinną siedzibę - oparł się na częstokole i zadumał. Fałszywe było zapewnienie rządcy, który hrabiemu ręczył, że Ostap nie ma krewnych nawet we wsi. [...] Ostap miał zawracać się już do dworu, ale serce wiodło go gdzie indziej. Od pierwszego kroku za wrota, ciągnął się ku cmentarzowi - mogiła matki i ojca wlokła go ku sobie. Ale żądanie to, wśród nocy, tak się musiało dziwnem wydać Fedkowi, że o niem nie śmiał wspomnieć! ${ }^{46}$.

Czyli mamy przed sobą dzieło przesiąknięte nie tyle społecznym patosem, ile pewnym nastrojem filozoficznym; dzieło, które w pewien sposób związane jest tak z folklorem, jak i z tradycjami homiletyki „wieku jezuitów”, które na początku XIX w. zostały bardzo mocno ugruntowane

45 Tamże, s. 22.

46 Tamże, s. 68. 
w polszczyźnie. To nie jest przypadkowa domieszka stylistyczna. J.I Kraszewski przywiązywał dużą wagę do cywilizacyjnej roli chrześcijaństwa, co widać m.in. w jego powieściach historycznych o Litwie ${ }^{47}$. Autor Ostapa Bondarczuka był zawsze głęboko religijny:

Nie był on nigdy prorokiem zwątpienia, nie siał goryczy, nie waśnił. W jego dziele literackiem jest często wielka boleść, są łzy serdeczne, niezmierna tęsknota, pesymizmu nie ma. Natomiast zawsze promyk nadziei, słowo otuchy, pokrzepienia i wiary. Tak, wiary! Bo jeśli w tym względzie przyjmował on chwilowo i dawał wyraz zmiennym prądom opinii, to zawsze gruntem jego przekonań była głęboka religijność i wiara ${ }^{48}$.

A obserwując szaleńczą autoafirmację niezliczonych nuworyszy epoki napoleońskiej - nowych Europejczyków wyrosłych w burzliwych czasach przemian cywilizacyjnych i kulturowych, pisarz nie mógł powstrzymać się od odczuwania zbliżającego się kryzysu społecznego. J.I. Kraszewski przedstawia ludzi, o których dokładnie powiedziano: „człowiek Zachodu zachował kulturę chrześcijańską, imperatywy ciągłego ruchu naprzód, nieustanną autotranscendencję, dążenie do «doskonałości», ale stracił [...] głęboką religijność znaczenia tego ruchu, jego treść i uzasadnienie” ${ }^{49}$.

Bondarczuk, który przypadkowo znalazł się w kręgu szlachty, nie czuje zachęcającego głosu losu. Czy to naprawdę wspaniałe samo w sobie? Czy cierpiałby więcej, gdyby pozostał wiejskim sierotą? - pyta J.I. Kraszewski, jakby w ukryciu. Oznacza to, że Ostap jest sparaliżowany moralnie, nie odważy się skonfrontować z możliwościami, które się przed nim otworzyły. Dlatego praca lekarza nie daje mu satysfakcji (należy poważnie przemyśleć kwestię pozytywizmu u J.I. Kraszewskiego).

I dlatego muszę przyznać, że genialna formuła Johna Locke'a - „Urodziliśmy się z takimi zdolnościami i mocami, które zawierają zdolność

47 V.I. Tubelevič, Istoriâ hristianskih konfeccij vKL v trudach I. Kraševskogo, [w:] Razvitie metodologičeskih issledovanij i podgotovka kadrov istorikov v Respublike Belarus', Rossijskoj Federacii i Respublike Pol'ś. Sbornik naučnyh statej, Grodno 2012 [В.И. Тубелевич, История христианских конфессий вкА в трудах И. Крашевского, [w:] Развитие методологических исследований и подготовка кадров историков в Республике Беларусь, Российской Федерации и Республике Польша. Сборник научньх статей, Гродно 2012], s. 215-219.

48 A. Krechowiecki, Józef Ignacy Kraszewski, „Pamiętnik Literacki” 1912, z.3, s. 373. Cyt. za: M. Szladowski, Ciemne świecidta nadziei - starość Józefa Ignacego Kraszewskiego (na przyktadzie „Nocy bezsennych”), „Wiek xIx. Rocznik Towarzystwa Literackiego imienia Adama Mickiewicza” 2012, R. 5 (47), s.349.

49 O. Balla, Psihoterapevtičeskaâ utopiâ i projekt Moderna, „Znanie-Sila” 2005 [О. Бамма, Психотерапевтическал утопия и проект Модерна, „Знание-Сима” 20о5], nr I2, s. 29. 
opanowania prawie każdej rzeczy i które w każdym razie mogą nas wyprowadzić poza to, co możemy sobie wyobrazić, ale tylko ćwiczenie tej siły mogą dać nam umiejętności i sztukę we wszystkim i doprowadzić nas do doskonałości" ${ }^{50}$ - jest prawdziwa tylko wtedy, gdy dana osoba naprawdę chce takiego ćwiczenia. Ale częściej człowiek po prostu boi się nieznanego. Jak zauważył Radosław Rak, poprzedzając swój tekst wymownym epigrafem "Zawsze to lepiej być panem niż chamem”, szlachcica i chłopa różni „przede wszystkim strach. Być chamem to żyć w lęku jak zając na miedzy, to [...] nie mieć wiele, ale drżeć przed utratą tego, co się posiada. [...] Chamstwo - to lęk. Pan zaś jest jastrzębiem na niebie i lwem na pustyni, i niczego nie musi się bać”. Niepokój budzić może nawet chwilowa poprawa losu: „Doświadczenie pokoleń chamów mówiło wyraźnie, że zmiany bywają albo na złe, albo na jeszcze gorsze; a jeśli coś pozornie zmienia się na lepsze, to prędzej czy później ta lepszość i tak wyjdzie bokiem" ${ }^{\text {11 }}$.

Mądrość ludowa uczy: „Nie będzie pana z chama” i wydaje się, że autor dokładnie to chce powiedzieć; w rzeczywistości, wbrew swojej reputacji „rzecznika ludu”, krytycznie przemyślał popularny XIX-wieczny mit o nieszczęsnym, biednym chłopie. Ale czy to oznacza, że autor lekceważy problematykę awansu społecznego? Chłopi urodzeni w XIX i XX w. współtworzyli elitę: np. rosyjski aktor Michaił Szczepkin, ukraiński poeta T. Szewczenko, amerykański naukowiec o chłopskich, ukraińskich korzeniach Iwan Puluj. Chłopi zasilali ruchy demokratyczne, inteligencję artystyczną, kręgi dziennikarskie itp. Urbanizacja, która rozwinęła się w najszerszy możliwy sposób w XX i XXI w., dostarcza niewyczerpanej listy takich biografii.

Jakie jest zatem znaczenie powieści J.I. Kraszewskiego? To fakt, że nie jest wcale konieczne, aby każdy z klasy chłopskiej musiał osiągnąć awans społeczny. Na przykład, w komunistycznym systemie totalitarnym w ZSRR, w którym chłopstwo było znienawidzone i dosłownie fizycznie eksterminowane (w latach 30. XX w. podczas wielkiego głodu -Hołodomoru w Ukrainie), a ocalały materiał ludzki został w przemyślany sposób usunięty ze wsi i wtłoczony w nowe ramy. W powojennej Ukrainie przez wiele dziesięcioleci z rzędu kandydaci ze wsi byli zapisywani na uniwersytety (mieli być przyjęci w $80 \%$ ), co dało początek potwornej pseudomorfozie. Ostatecznie „inteligencja radziecka” składała się z ludzi przyzwyczajonych od

50 Čelovek. Mysliteli prošlogo inastoâsego o ego žizni, smerti i bessmertii. Drevnij mir - êpoha Prosveŝeniâ, red. I.T. Frolov i dr., Moskva 199і [Человек. Мыслители проилого и настоямего о его жизни, смерти и бессмертии. Аревний мир - эпоха Просвещения, реА. И.Т. Фролов и ар., Москва г99і ], s. 343.

51 R. Rak, Baśń o wężowym sercu albo wtóre stowo o Jakóbie Szeli, Warszawa 2019, s. 280-282. Na temat sytuacji chłopów zob. szerzej: K. Pobłocki, dz. cyt., passim. 
dzieciństwa do chłopskiego stylu życia, którzy umieją paść krowy, karmić świnie, ale nie są w żaden sposób gotowi do rozwiązywania problemów intelektualnych i często nie mają pojęcia o ogólnej i światowej kulturze duchowej. Nie po to, żeby zrujnować kulturę ukraińską, ale żeby spowolnić jej rozwój do skrajności. A J.I. Kraszewski, już u zarania tego procesu, w rzeczywistości mądrze przypomniał, że Bóg i Natura stawiają granice pięknej idei zrównania wszystkich w jednej chwili, w szczególności szlachty i chłopstwa. Równoległe linie Euklidesa na ogół nie przecinają się. Ale czy to naprawdę jest źródłem tragedii?

„Idź do mrówki, leniwcze, przypatrz się jej postępowaniu, abyś zmądrzal" - mówi biblijny Salomon (PS: 6, 6). Rzeczywiście, w bezpretensjonalnym chłopskim życiu na łonie natury ujawnia się nie tylko „idiotyzm wiejskiego życia”, jak arogancko ujął to współczesny J.I. Kraszewskiemu Karol Marks. W chłopskiej chacie toczy się to samo pełnoprawne życie ludzkie, co w pałacu z jego rodzinnymi portretami, kaplicą i salą bilardową. Najwyraźniej Ostap był przeznaczony do tego życia, ale era „rewolucyjno-wyzwoleńcza", nie pytając nikogo, zmieniła tutaj znaki, jak burza u Hansa Christiana Andersena.

Można w tym zobaczyć odzwierciedlenie ideału Jeana-Jacques’a Rousseau, ale gdy J.I. Kraszewski interpretuje idee Oświecenia, jest skłonny sięgać głębiej niż sami oświeceniowcy, jakby odsłaniając źródła ich tez. W tym przypadku nie jest to fałszywa idealizacja „pejzana”/wieśniaka ani oczernianie "chama”, który jest tym samym nieodzownym składnikiem porządku świata społecznego, jak wszystkie inne stany. Być może mamy do czynienia z podobieństwem do indyjskiej koncepcji warn: funkcję kapłańską przydzielono Semowi, królewsko-wojskową - Jafetowi, a rolniczą - Chamowi. Podobnie jak w przypadku trzech wielorybów, na tych grupach wspierało się archaiczne społeczeństwo. A wartości świata chłopskiego są w takim samym stopniu złotym funduszem kultury, jak np. struktura liturgii czy poezja rycerska.

\section{Wnioski końcowe}

W artykule przedstawiono tezę, że zamysł autora powieści Ostap Bondar$c z u k$ polega na przeciwstawieniu wirowym nieprzewidywalnym prądom nowoczesności i nadchodzącym z Francji „napoleońskim” możliwościom epoki pozwalającym na niemożliwy dotąd awans społeczny, pewnego ukrytego programu metafizycznego. Pozytywiści odebraliby go jako „naturalny”, ale sam pisarz zinterpretowal to raczej w duchu romantycznej, popularnej mądrości chrześcijańskiej. Ostatecznie perspektywa J.I. Kraszewskiego, dotycząca wyjścia człowieka poza granice swojej klasy i uwarunkowanej 
przez nią mentalności, jest utrudniona przez trwałość programu opartego na biblijno-folklorystycznym archetypie pierwotnej fizycznej i społecznej nierówności ludzi, równych sobie tylko w grzechu pierworodnym. Mimo całej szczerości pragnienia hrabiego, aby zamienić chłopskiego prostego "Ostapa” w nowoczesnego Europejczyka „Eustachego”, główny bohater nie wykazuje śmiałości i umiejętności wyjścia poza szablon określony z góry przez narodziny i pierwsze lata życia. A fakt, że Ostap wbrew jego woli „zmienił swój los”, nie uczynił go naprawdę wolnym i szczęśliwym. Prawdziwej przemiany roli społecznej dokonuje się nie przez „bajeczne” miłosierdzie z zewnątrz, ale przez osobistą ciężką pracę i bezinteresowne oddanie: byłoby to interesujące dla pozytywisty. Innymi słowy, nadal mamy do czynienia z zasadniczo romantycznie integralną mono-postacią bohatera. $\mathrm{Z}$ drugiej strony, J.I. Kraszewski tylko częściowo i bardzo płynnie posługiwał się pozytywistycznymi indywidualnymi metodami przedstawiania człowieka w dynamicznym środowisku, co wzbogaciło styl autora, ale nie zmieniło jego metody artystycznej.

\section{Bibliografia}

\section{Literatura}

Bachorz J., Poszukiwanie realizmu. Studium o polskich obrazkach prozq w okresie międzypowstaniowym $1831-1863$, Gdańsk 1972.

Balla O., Psihoterapevtičeskấ utopiâ i projekt Moderna, „Znanie-Sila” 2005 [Балма O., Психотерапевтическая утопия и проект Модерна, „Знание-Сика” 2005], nr I2.

Bar A., Charakterystyka i źródta powieści Kraszewskiego w latach 1830-1850, Warszawa, 1934.

Bazylow L., Spoteczeństwo rosyjskie w pierwszej potowie XIX w., Wrocław 1973.

Budrewicz T., „Zdrowie” i „choroba” w jezyku Kraszewskiego (w okresie wotyńskim), [w:] Budrewicz T., Kraszewski - przy biurku i wśród ludzi, Kraków 2004.

Chmielowski P., Józef Ignacy Kraszewski. Zarys biograficzno-literacki, Kraków I888.

Czachowski K., Józef Ignacy Kraszewski, [w:] Czachowski K., Między romantyzmem a realizmem, Warszawa 1967.

Čelovek. Mysliteli prošlogo i nastoâsêgo o ego žizni, smerti i bessmertii. Drevnij mir - êpoha Prosveŝeniâ, red. I.T. Frolov i dr, Moskva 1991. [Человек. Мыьслители прошлого и настоящего о его жизни, смерти и бессмертии. Аревниймир - эпоха Просвещения, реА. И.Т. Фролов и ар., Москва 1991].

Čornous S., Ukraïnika u tvorčosti U.İ. Kraševs'kogo, „Kiïvs'kì Polonìstičnì Studïi” 2006, t. 7: „Ukraïns'ka škola” v literaturi ta kul'turi ukraïns'ko-pol's'kogo pograničcâa, Kiїv. [Чорноус C., Україніка у творчості Ю.І. Крашевського, „Київські Помоністичні СтуАії” 2006, т. 7: „Українська школа” в літературі та культурі українсько-польського пограниччя, Киї].

Danek W., Sylwetka ideowa J.I. Kraszewskiego, „Ruch Literacki” 1962, z. 6.

Epsztein T., Wielka wtasnośćziemska w gubernipodolskiej na tle Ukrainy Prawobrzeżnej w XIX wieku, 
"Studia z Dziejów Rosji i Europy Środkowo-Wschodniej” 20I8, nr I.

Głowiński M., Gatunek literacki i problemy poetyki historycznej, [w:] Proces historyczny w literaturze i sztuce. Materiaty konferencji naukowej. Maj 1965, Warszawa 1967.

Gorodeisky K., Igth Century Romantic Aesthetics, [w:] The Stanford Encyclopedia of Philosophy. Dostępny w Internecie: https://plato.stanford.edu/entries/aesthetics-19th-romantic/

Grabias-Banaszewska K., Sytuacja narracyjna w opowiadaniu Józefa Ignacego Kraszewskiego „Życie po śmierci. Powieść pijaka”, [w:] Ûzef Kraševs'kij v kul'turnij spadŝini Ukraïni ta Pol'sì. Zbirnik naukovih prac' za materiatami mižregional'nogo naukowo-praktičnogo ceminary iz mižnarodnoûy častû, 20 grudnâ $20 I 7$ roku, m. Żitomir, red. O.P. Poliŝuk, B. Troha, V.O. Êršov, M.A. Kozlovec', N.A.Sejko, Žitomir 2017. [Юзеф Крашевський в культурній спадшині України та Польщі. Збірник наукових пращь за матеріалами між регіонального науковопрактичного семінару із міжнародноюу частю, го грудня 2017 року, м. Житомир, реА. О.П.Поліщук, Б. Троха, В.О. Єршов, М.А. Козмовець, Н.А. Сейко, Житомир 2017].

Herberstein S. von, Rerum moscoviticarum commentarii, Bazylea 1549.

Ihnatowicz E., Proza Kraszewskiego. Codzienność, Warszawa 201 .

Janion M., Żmigrodzka M., Romantyzm i historia, Gdańsk 2001.

Jeż T.T. [Zygmunt Miłkowski], Wasyl Hotub, Kraków 1909.

Kącka E., Cztowiek wedtug Smilesa. Kraszewskipozytywistów (Struve, Chmielowski, Orzeszkowa), „Wiek xIx. Rocznik Towarzystwa Literackiego im. Adama Mickiewicza” 20I2, R. V (47).

Kijas J., Kraszewski wobec kwestii chtopskiej w latach I840-1862, „Zeszyty Naukowe Uniwersytetu Jagiellońskiego”, nr 13 "Seria Nauk Społecznych, Filologia. Prace Historyczno-Literackie”, z.3, Kraków 1957.

Kostâkevič K., Ûzefİgnacij Kraševs'kij âk majster romantičnogo opisu ukraïns'kih selân XIX stolittâ, [w:] Ûzef Kraševs'kij v kul'turnij spadsinini Ukraïni ta Pol'ši. Zbirnik naukovih prac' (za materiatami mižregional’nogo naukowo-praktičnogo seminaru iz mižnarodnôे učastû, 20 grudnâ 2017 roku, m. Żitomir), Źitomir 2017 (Косякевич К., Юзеф Ігнацій Крамевськийякмайстер романтичного опису українських селян хІх століттяя, [w:] Юзеф Крашевський в культурній спадщині України та Польщі. Збірник наукових пращь (за матеріалами міжрегіонального науково-практичного семінару із міжнародною участю, 20 грудня 2017 року, м. Житомир), Житомир 2017.

Kozłowska A.A., Fizjonomiczne ślady w epoce pozytywizmu na przyktadzie „Dziwadet” J.I. Kraszewskiego, „Annales Universitatis Mariae Curie-Skłodowska” 2016, sectio FF - Philologia, vol. XXXIV, nr I.

Kraszewski J.I., Ostap Bondarczuk, Lwów i875.

Krechowiecki A., Józef Ignacy Kraszewski, „Pamiętnik Literacki” 1912, z. 3.

Leszczyński A., Ludowa historia Polski. Historia wyzysku i oporu. Mitologia panowania, Warszawa 2020.

Litwinowicz-Droździel M., Józef Ignacy Kraszewski i choroby wieku, [w:] Kraszewski i wiek XIX. Studia, red. A.Janicka, K. Czajkowski, P. Kuciński, Białystok 2014.

Lul M., Drzewo, cztowiek i drobnoustroje w powieściowym laboratorium. O „Historii kotka w ptocie” Józefa Ignacego Kraszewskiego, „Annales Universitatis Paedagogicae Cracoviensis. Studia Poetica" 2020, $\mathrm{nr} 8$.

Lul M., Wielkim nudziarzem byt? Kraszewski, blogspot i czytanie klasyki, [w:] Kraszewski i wiek XIX. Studia, red. A. Janicka, K. Czajkowski, P. Kuciński, Białystok 2014. 
Ławski J., Józef Ignacy Kraszewski - nowe style lektury, „Volin'-Žitomirŝina” 2014 [„ВолиньЖитомирщина”. Історико-фікологічний збірник з регіонамьних проблем, Житомир 20I4], $\mathrm{nr} 25$.

Malûkovič S.D., Stanovlenie realizma v tvorčestve Ûzefa Kraševskogo (povesti i pomany 30-4o-h godov), Diss.... kandydata filologičeskih nauk, Moskva 1984. [Малюкович С.А., Становление реализма в творчестве Юзефа Крашевского (повести и романы зо-4о-х годов), Аисс. ... кандидата филологических наук, Москва 1984].

Markiewicz H., Literatura pozytywizmu, Warszawa 1986.

Matuszewski J., Geneza polskiego chama Studium semazjologiczne, „Acta Universitatis Lodziensis” 1982, Folia iuridica, t. XI.

Nagielski M., Ukraińcy, [w:] Pod wspólnym niebem. Narody dawnej Rzeczypospolitej, pod red. M. Kopczyńskiego i W. Tygielskiego, Warszawa 2010.

Nazirov R.G., Ditâv vorzine i primety izobrannikov. Opyt rekonstrukcji êtnografičeskogo substrata mifov, „Nazirovskij Arhiv” 2016 [Назиров Р.Г., Аит явко рзинеиприметьизбранников. Опьт реконструкщии этнографического субстрата мифов, „Назировский Архив” 2016], nr 4. Dostępny w Internecie: http://nevmenandr.net/nazirov/journal.php.

Nowina-Sroczyńska E., Przezroczyste ramiona ojca. Etnologiczne studium o magicznych dzieciach, Łódź 1997.

Petričenko N., Volin'i Žitomirŝina - druga bat'kivsina Û.İ. Kraševs'kogo (ukraïns'ki zacikavlennâ, tematika, žanrova naraciâ prozovoï spadsinini pis’mennika), „Volin'-Žitomirŝina” $2009, \mathrm{nr} 19$. [Петриченко Н., Волинь і Житомирщина - друга батьківщина Ю.І. Крашевського (українські зачікавлення, тематика, жанрова нарація прозової спадщини письменника), „Волинь-Житомирщина”. Історико-філологічний збірник з регіональних проблем, Житомир 2009].

Pobłocki K., Chamstwo, Wołowiec 2021.

Prokofjewa D.S., JózefIgnacy Kraszewski w prasie rosyjskiej drugiejpotowy XIX wieku, „Pamiętnik Literacki" 1965 , z. 2.

Rak R., Baśń o wężowym sercu albo wtóre stowo o Jakóbie Szeli, Warszawa 2019.

Rauszer M., Chtop-niewolnik? Pańszczyzna w perspektywie antropologii historii, „Lud” 2017, t. IOI.

Ševčenko T.G., Povnezibrannâ tvoriv. U I2 t., red. M.G. Žylins'kij ta ìn., t. 2: Poeziâ I847-I86I, Kiïv 20ог. [Шевченко Т.Г., Повнезібрання творів. У 12 m., реА. М.Г. Жулинський та ін., т. 2: Поезія 1847-186I, Київ 200I].

Sienkiewicz T.W., Intertekstual'nost' romana "Maslav" U.I. Kraševskogo, [w:] Kraszewski i wiek XIX. Studia, red. A.Janicka, K. Czajkowski, P. Kuciński, Białystok 2014. [Sienkiewicz T.W., Интертекстуальность романа „Маслав" Ю.И. Крашевского, [w:] Kraszewski i wiek ХIX. Studia, red. A. Janicka, K. Czajkowski, P. Kuciński, Białystok 2014].

Sokyrska W.W., Strogosz T., Hajdamacy i koliszczyzna w historiografii polskiej i ukraińskiej. Polsko-ukraiński dwugtos, „Przegląd Nauk Historycznych” 2017, nr 2.

Sowa J., Inna Rzeczpospolita jest możliwa! Widma przesztości, wizje przysztości, Warszawa 2015.

Stomma L., Polskie ztudzenia narodowe, Poznań 2006.

Szladowski M., Ciemne świecidta nadziei - starość Józefa Ignacego Kraszewskiego (na przyktadzie „Nocy bezsennych”), „Wiek XIx. Rocznik Towarzystwa Literackiego imienia Adama Mickiewicza" 20I2, R.5 (47). 
Szulska I., Litwa Józefa Ignacego Kraszewskiego, Warszawa 201 I.

Trembecki S., Sofjówka, Warszawa 2000.

Tubelevič V.I., Istoriâ hristianskih konfessij VKL v trudach I. Kraševskogo, [w:] Razvitie metodologičeskih issledovanij i podgotovka kabrov istorikov v Respublike Belarus', Rossijskoj Feberacii i Respublike Pol'sa. Sbornik naučnyh statej, Grodno 2012. [Тубелевич В.И., История христианских конфессий вкА в трудах И. Крашевского, [w:] Развитие методологических исследований и подготовка кадров историков в Республике Беларусь, Российской Федерачии и Республике Польша. Сборник научных статей, Гродно 2о12].

Ûng K.G., Ob Otnošenii analitičeskoj psihologii k poêtiko-hudožestvennomu tvorčestvu, [w:] Ûng K.G., Sobranie sočinenij v Ig tt., t. Is: Fenomen duha v iskusstve i nauke, Moskva 1992. [Юнг К.Г., Оботношении аналитической психологии к поэтико-художественному творчеству, [w:] Юнг К.Г., Собрание сочинений в го тт., т. І5: Феномен духа в искусстве и науке, Москва 1992].

Warzenica E., „Powieści romantyczne” J.I. Kraszewskiego, [w:] Z teorii i historii literatury. Prace poświęcone V.Międzynarodowemu Kongresowi Slawistów w Sofii, red. K. Budzyk, WrocławWarszawa-Kraków 1963.

Wojciechowski K., Historia powieści w Polsce. Rozwój typów i form romansu polskiego na tle porównawczem, Lwów 1925.

Zawodziński K.W., Studia o Kraszewskim, [w:] Zawodziński K.W., Opowieści o powieści, Kraków 1963.

Zelìns'ka L.V., Vidobražennâ ,seredn'ogo klasu” u malârstvi ta literaturi Rosijskoï imperï dr.pol. XVIII - per. pol. XIX st., „Naukovì zapiski Nacional'nogo unìversitetu. Ostroz'ka akademiâ”,

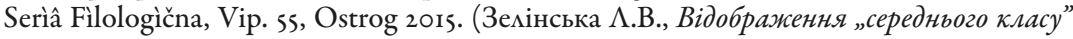
у малярстві та літературі Російської імперї̈ др. пол. ХVIII - пер. пол. ХIX ст., „Наукові записки Національного університету. Острозька академія”, Серія Фікологічна, Вип. 55, Острог 2015).

Zielonko E., JózefIgnacy Kraszewski w wydaniach Ludowej Spótdzielni Wydawniczej, „Rocznik Towarzystwa Literackiego imienia Adama Mickiewicza” 1986, R. 21.

Żmigrodzka M., Orzeszkowa. Mtodość pozytywizmu, Warszawa 1965.

Żmigrodzka M., Polska powieść biedermeierowska, „Pamiętnik Literacki” 1966, t. 52, z. 2.

Żmigrodzka M., Proza fabularna w kraju, [w:] Obraz literatury polskiej XIX $i_{X X}$ wieku, Seria 3, t. I: Literatura krajowa w okresie romantyzmu ${ }_{183}{ }_{3-1863}$, red. M. Janion, B. Zakrzewski, M. Dernałowicz, Kraków 1975.

Żok D., JózefIgnacy Kraszewski - niedoceniony izapomniany wpolskiejszkole, [w:] ÛzefKraševs'kij v kul'turnij spadŝini Ukraïni ta Pol'ši. Zbirnik naukovih prac'za materiatami mižzregional'nogo naukowo-praktičnogo seminary iz mižnarodnoûy častû, 20 grudnâ 2017 roku, m. Žitomir, red. O.P. Poliŝuk, B. Troha, V.O.Êršov, M.A. Kozlovec', N.A. Sejko, Žitomir 2017. [Юзеф Крамевський в культурній спадщині України та Польщі. Збірник наукових пращь за матеріалами між регіонального науково-практичного семінару із міжнародноюу частю, 20 грудня 2017 року, м. Житомир, реА. О.П. Поміщук, Б. Троха, В.О. Єршов, М.А. Козмовець, Н.А. Сейко, Житомир 2017].

Streszczenie: Autor artykuł rozpatruje powieść J.I. Kraszewskiego Ostap Bondarczuk w scenerii wirowych prądów nowoczesności i nowych możliwości epoki napoleońskiej oraz pewnego ukrytego programu metafizycznego, który w tym ujęciu byłby postrzegany 
przez pozytywistów jako „naturalny”. Zwraca uwagę, że pisarz swoją powieść zinterpretował raczej w duchu romantycznej chrześcijańskiej mądrości ludowej. Ostatecznie sam Kraszewski wyszedł poza granice swojej klasy i uwarunkowanej przez nią mentalności. „Wyzwolenie samego siebie" jest utrudnione przez przypisanie człowieka do jego oryginalnego programu. Program ten oparty jest na biblijno-folklorystycznym archetypie pierwotnej fizyczno-społecznej nierówności ludzi. Mimo całej szczerości pragnienia hrabiego, aby przekształcić Ostapa w „swojego”, czyli w „Eustachego”, przy wielkich wysiłkach tego ostatniego, aby spełnić nadzieje „nowych rodziców”, główna postać nie wykazuje odwagi, zdolności do zdecydowanego wyjścia poza szablon określony z góry przez narodziny i pierwsze lata życia. Fakt, że Ostap wbrew swojej woli „odmienił swój los”, nie uczynił go naprawdę wolnym i szczęśliwym. Prawdziwa zmiana roli społecznej dokonuje się nie przez „wspaniałe" miłosierdzie z zewnątrz, ale osobistą ciężką pracą i bezinteresowne poświęcenie - takie spojrzenie byłoby interesujące i zgodne z nurtem pozytywizmu. Wciąż jednak mamy do czynienia z romantyczną konstrukcją bohatera. Z drugiej strony J.I. Kraszewski tylko częściowo i bardzo płynnie wykorzystywał pozytywistyczne indywidualne metody przedstawiania osoby w dynamicznym środowisku jako materiale dodatkowym, co wzbogacało styl autora, ale nie zmieniało jego metody artystycznej.

Słowa klucze: chłopi, szlachta, sprawiedliwość społeczna, archetyp, romantyzm, realizm, chrześcijaństwo

Summary: The article highlights the fact that the author's deep setting consists in opposing the eddy currents of modernity and the bright "Napoleonic" possibilities of the era to a certain hidden metaphysical program, which would be perceived by positivists as "natural". Nevertheless, but the writer himself interpreted it more in the spirit of romanticized Christian folk wisdom. Ultimately, Krashevski's perspective for a person to go beyond the limits of his class and the mentality conditioned by it, to "liberate himself," is hampered by the persistence of this original program. Theprogram is based on the biblical-folklore archetype of the primordial physical-social inequality of people, equal only in original sin. For all the sincerity of the count's desire to turn Ostap into "his", into "Eustachiy", with all the efforts of the latter to justify the hopes of the new parents, the central character does not show daring, the ability to seriously go beyond the stencil predetermined by birth and the first years of life. And the fact that Ostap, against his will, "changed his fate", did not make him really free and happy. A genuine change in social role is achieved not by "fabulous" mercy from the outside, but by personal hard work and selfless devotion: this would be of interest to the positivist. In other words, we are still dealing with a fundamentally romantically integral mono-character of the protagonist. On the other hand, J.I Krashevski only partially and very fluently used the positivist individual methods of depicting a person in a dynamic environment as additional material, which enriched the author's style, but did not change his artistic method.

Keywords: peasants, gentry, social justice, archetype, romanticism, realism, Christianity 